\title{
An Example Of Bioclimate Architecture In Bosnia And Herzegovina: Bosnian Chardaklia House In Gorani Near Konjic
}

\author{
Ahmet Hadrovic \\ Faculty of Architecture, University of Sarajevo, Sarajevo, Bosnia and Herzegovina \\ DOI - http://doi.org/10.37502/IJSMR.2022.5103
}

\begin{abstract}
Bosnia and Herzegovina has a wide range of architectural programs of traditional architecture which, according to its concept, design and materialization has the characteristics of bioclimatic architecture: houses (main and auxiliary-seasonal), barns, utilitarian architecture (mills, handicrafts), sacral (mosques), turbe, church)...

The Bosnian chardaklia house is one of the most authentic achievements of traditional architecture in Bosnia and Herzegovina. As a residential building, it most fully reflects the housing culture of the Bosnian-Herzegovinian man, and his overall view of the world. The Bosnian chardaklia house of reached its classical stage of development in the 18th century, and the solutions reached will be maintained during the 19th and 20th centuries, in some places until today. Unlike the city house (which in Bosnia and Herzegovina, similarly elsewhere in the world, was generated with more or less pronounced influences of other cultures), the Bosnian chardaklia house directly reflects the natural environment of Bosnia and Herzegovina and the social environment, socio-economic relations, philosophy, religion, morals ...).

Bosnia and Herzegovina is rich in forests and building stone of various performances, from that stone suitable for masonry, stone suitable for making floor coverings to stone slabs suitable for making roofing. This fact is directly reflected in the generation of the spatial concept of the house, its construction and materialization.

The presented example of the Bosnian chardaklia house in Gorani near Konjic retains the basic concept of the developed type of this house, but in its architectural-spatial concept is more modest (rooms are smaller, no sofa), which is a direct consequence of colder climate and dominance of stone over wood - as a basic building material.
\end{abstract}

Keywords: man, wood, autochthonous architecture, bioclimatic architecture, materialization in architecture.

\section{Introduction}

Bosnia and Herzegovina is situated in Southeast Europe, in an area where two different climatic zones intersect (Mediterranean belt and continental climate zone), with a number of 
transitional forms (sub-Mediterranean climate, mountain climate, temperate-mountain climate) ${ }^{[1,2]}$, (Figure 1.).

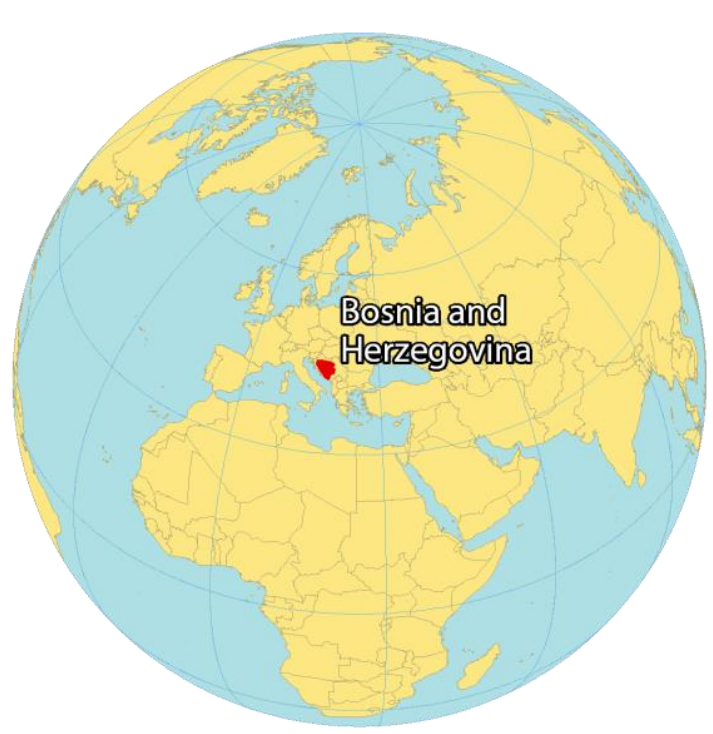

a)

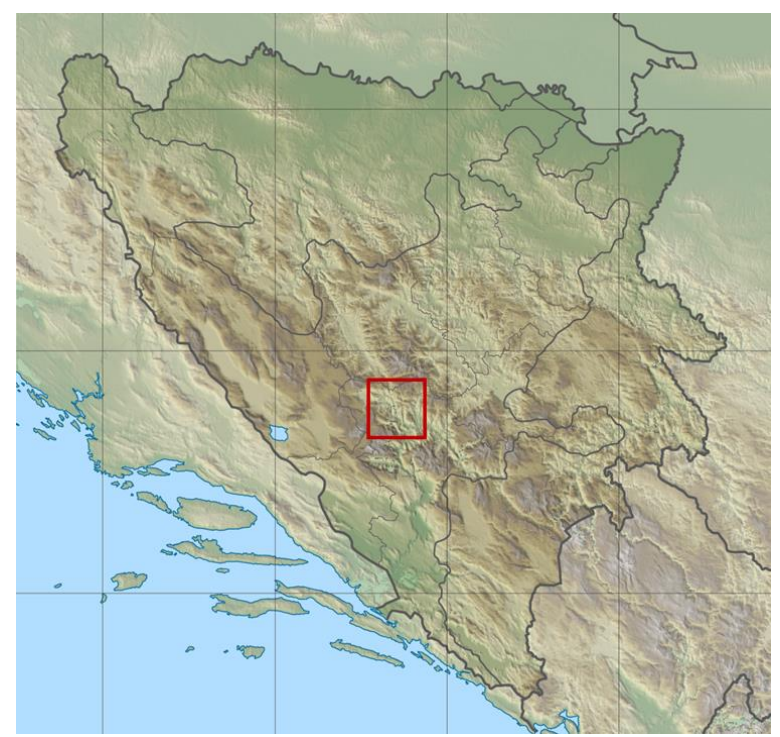

b)

\section{Figure 1. Geographical position (a) and geomorphology of Bosnia and Herzegovina (b)}

Source:

https://gisgeography.com/bosnia-and-herzegovina-map/, Accessed: 12.23.2021. (left) https://www.mapsland.com/maps/europe/bosnia-and-herzegovina/detailed-relief-map-ofbosnia-and-herzegovina.jpg Accessed: 12.23.2021. (right)

The diversity of the climate is largely, along with the geographical location and global distribution of land and sea, the result of geomorphology, where the Dinaric Massif (stretching from northwest to southeast Bosnia and Herzegovina) creates a huge natural barrier between the Adriatic Sea in the south and the vast Pannonian Plain in the north. The High Dinaric Massif (average altitude of 1500-2200 m) is a natural "catcher" of precipitation (snow and rain). In its porous geological structure (limestone) there are huge accumulations of water which, and at its foot many natural sources of a large number of rivers (Neretva, Drina, Bosnia, Vrbas, Una, Pliva, Krivaja, Drinjaca...). In addition to numerous streams and rivers, in Bosnia and Herzegovina there are many natural lakes (Boracko, Busko, Prokosko, Blidinje, Balkans, Satorsko, Deransko...), which themselves become "shapers" of the climate in the local context.

Bosnia and Herzegovina is an area with a different geological structure. In the profile southwest - northeast, from the Adriatic Sea to the Sava River, the following paleogeographic-structural units can be distinguished:

- Dinaric carbonate platform (Outer Dinarides), mostly in the Adriatic Sea basin and smaller in the Sava River Basin,

- Bosnian flysch, Sava river basin, 
- Paleozoic-Triassic allochthonous formations that to a lesser extent belong to the Adriatic Sea Basin and to a greater extent to the Sava River Basin. The basin of the Adriatic Sea includes the southwestern parts of the mountains Zec, Bitovnja and Bjelasnica (Neretva River Basin). The Sava River Basin includes the Paleozoic and Triassic terrains of the Kljuc, Sanski Most, Vranica, Igman and Bjelasnica mountains, the wider Sarajevo and Gorazde areas,

- Ophiolite zone which includes the mountains Ozren and Konjuh (typical non-karst terrain in which basic and ultrabasic rocks predominate), Sava sub-basin,

- Sava-Vardar zone (Tuzla and Posavina cantons), Sava sub-basin.

Within these paleogeographic-structural units, postorogenic Oligocene, Neogene and Quaternary formations have been singled out in which significant water bodies of intergranular porosity have been formed.

Geographical position, relief, river watercourses and lakes formed the climate of Bosnia and Herzegovina, which, along with the geological structure of the soil, generated the appearance of rich forests. Thus, wood has emerged as one of the key building materials in traditional architecture. In addition to wood, stone was (and still is) a very important building material that is always used in those elements of the structure of architectural structures where wood, due to its properties, cannot meet the required requirements (part of the structure of the building in the country). Throughout its history, Bosnia and Herzegovina has been a kind of "buffer zone" between different worlds (culture, religion, ideology...). For this reason, the culture of the people of Bosnia and Herzegovina is complex, with a more or less visible influence of cultures (from the East and from the West).

The natural and social environment determined the entire material and spiritual culture of the people of Bosnia and Herzegovina, in which the chardaklia house is one of its most authentic expressions ${ }^{[3,4,5,6,7]}$.

The spatial organization of the Bosnian chardaklia house was generated during the feudal social order of the Ottoman Empire (15th-19th century) in Bosnia and Herzegovina, and remained during the Austro-Hungarian administration (1878-1918), during the Kingdom of Serbs, Croats and Slovenes (1918-1929), the era of the Kingdom of Yugoslavia (1929-1941) and the era of the FPRY-SFRY (1943-1991), until today ${ }^{[8,9]}$. The Bosnian chardaklia house is the house of the richest layer of the rural population, so, as such, it was the basis on which the town house in Bosnia and Herzegovina was developed (primarily the oriental type) ${ }^{[10,11 \text {, }}$ $12,13,14]$. The family represented a more or less numerous "working community" consisting of the host with his wife and his sons with their wives and children ${ }^{1}$. What makes it specific is the fact that the Bosnian house was built with the intention of lasting through three or four generations of generations of one family, and then being dismantled. At the same time, its "demolition" did not mean its "destruction" since the complete material from which it was built was used (in the process of recycling) for the construction of a new house (house of a new generation), on its location.

\footnotetext{
${ }^{1}$ The female children of the host, as a rule, married early, while the host himself was in full physical strength.
} 
The bosnian chardaklia house, as a rule, developed on sloping terrain, through the basement, ground floor and first floor ${ }^{[8]}$. Sloping terrain was purposefully selected for its construction, since on the one hand, the undesirable influence of moisture from the terrain (in the halfburied floor, warehouses) was prevented, and on the other hand, storage space for more durable food was provided (at constant temperature). On the ground floor level, a main living area is organized for the whole family. This space is arranged on the ground (floor of compacted earth), with a fireplace. The hearth meant much more than the place where a fire was lit (to heat the space) and food was prepared; the hearth was a symbol of family community, the personification of home and existence. For this reason, this space was called a "house" ("kuća"). In the continuation of this space (above the space of the basement, ie the warehouse) are the rooms (main rooms) in which the oldest member of the family, the "head of the house", stayed with his wife. In some solutions, the rooms are organized on the other side of the "house", so that the space of the "house" occupied a central place in the horizontal plan of the house. The bosnian chardaklia house always implies the existence of a first floor, once the first and second floor. The vertical development of a house's space, as a rule, reflects more housing needs of its builder, a richer housing culture and more construction skills, ie the art of mastering physical space. The appearance of floors (sometimes two floors) results in the need to create vertical communications and create an inter-storey structure between two spatial levels. The appearance of the first floor always seeks the most suitable place to set up vertical communication, with the fulfillment of a controversial requirement: the spatialfunctional connection of the ground floor and first floor and the possibility of fully autonomous use of each level separately. In addition to the requirements for organizing the space, there are also the requirements for providing the comfort of the series (space heating and cooling, acoustic insulation, fire safety...).

Summarizing the requirements of the spatial organization of the bosnian chardaklia house, a key requirement is imposed: the possibility of dividing the space of the house "into $\mathrm{N}$ equal parts", both horizontally and vertically.

\section{House of the Smajic family in Gorani near Konjic}

The house of the Smajic family in Gorani near Konjic is located on a flat terrain, on a slope with a southeastern exposure (geographical coordinates: 43⒋ $53.02^{\prime \prime} \mathrm{N}, 1^{\circ} 48^{\prime} 08.54^{\prime \prime} \mathrm{E}$, Elevation: $511 \mathrm{~m}$ ), (Fig.). The house was built in the middle of the 19 th century ${ }^{2}$.

\footnotetext{
2 The author visited this house 8/4/2016. He was assisted in filming the house by Mr. Asim (Atif) Smajic (1947), whose ancestors built this house. Information on the culture of housing in the Gorani village near Konjic was provided to the author by: Smajic (Ahmet) Zikrija (1933), Hrnjica (Ismet) Bego (1941), Smajic (Atif) Asim (1947), Hrnjica (Taib) Sacir (1961), Smajic (nee Alibegovic) Ajisa (1963), Hrnjica (nee Pirija) Razija (1972).
} 


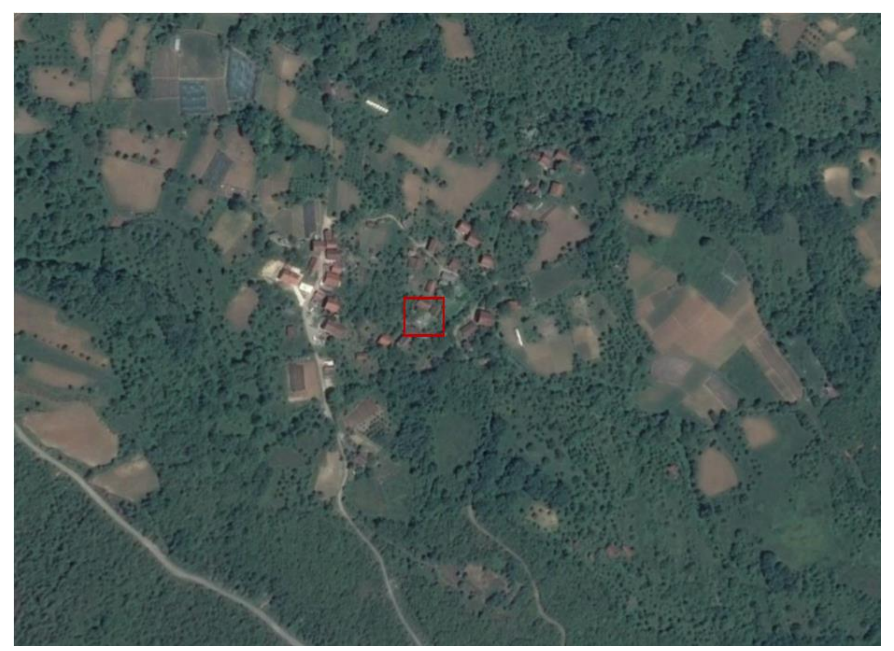

Figure 2. House of the Smajic family in Gorani near Konjic. The location

Source: Google Earth, accessed 10.28.2021.

\section{Spatial-form characteristics of the hous}

According to the disposition of horizontal plans, the Smajic family house in Gorani near Konjic belongs to the type of two-tract bosnian chardaklia house which is developed vertically through the basement, ground floor and first floor ${ }^{[8]}$, (Figure 3., a). Given its location, the house has the specifics of a Herzegovinian house where stone is the main building material, (Figure 3., b). The basement of the house (warehouse) is arranged just below part of the contour of the ground floor. It is the space of a large house pantry where groceries that were of a permanent character (fruit jam, cheese, butter) were kept. The basement walls, as well as the ground floor and first floor walls, are made of crushed stone, $70-80 \mathrm{~cm}$ thick. In the first tract of the ground floor, which was developed on the ground, there is a living room, "house" ("kuća"). The space was accessed from two, mutually opposite, sides, from two courtyards. The "house" ("kuća") has a fireplace (which is still there today in its original version), with an open space to the attic. From the space of the "house" one room is accessed and a narrow single-legged staircase (basamaci) leads to the floor level.

The staircase from the ground floor leads to the space of a narrow corridor at the floor level. This hallway is accessed in three chardaks, two above the room on the ground floor, and one above the space of the "house". In addition to this chardak, in the entire width of the "house" is a space of dimluk that connects the fireplace with the open space of the attic, (Figure 6.).

The roof is three-pitched, with a stone gable wall at the height of the "house" wall next to the terrain. The roof has a small slope as it is covered with stone slabs on densely placed beams, (Figure 3.).

All ceiling constructions are made of wooden beams with hewn wooden floors, (Figures 5., 7.). 
In one chardak there is (although devastated) a preserved spa (Bath tub - „banjica“), (Figure 12.).

All original elements of the opening have been preserved in their original design (Figures 4., 8., 10.).

Both the exterior and interior surfaces of the stone walls are plastered and whitewashed (Figures 3 (b)., 5.).

The floor covering in the "house" ("kuća") is made of stone slabs, while the floor in the rooms and chardaks is made of wooden floors with a covering of handmade rugs (carpets, woolen tarpaulins and woven cloth curtains), (Figure 4.).

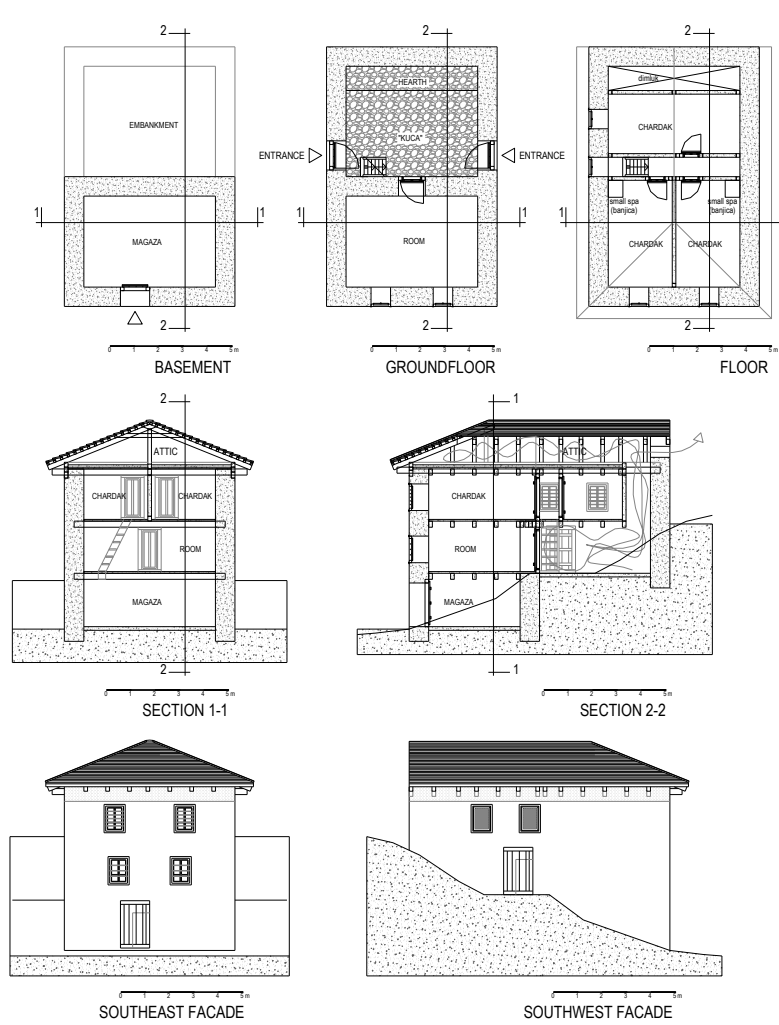

a)

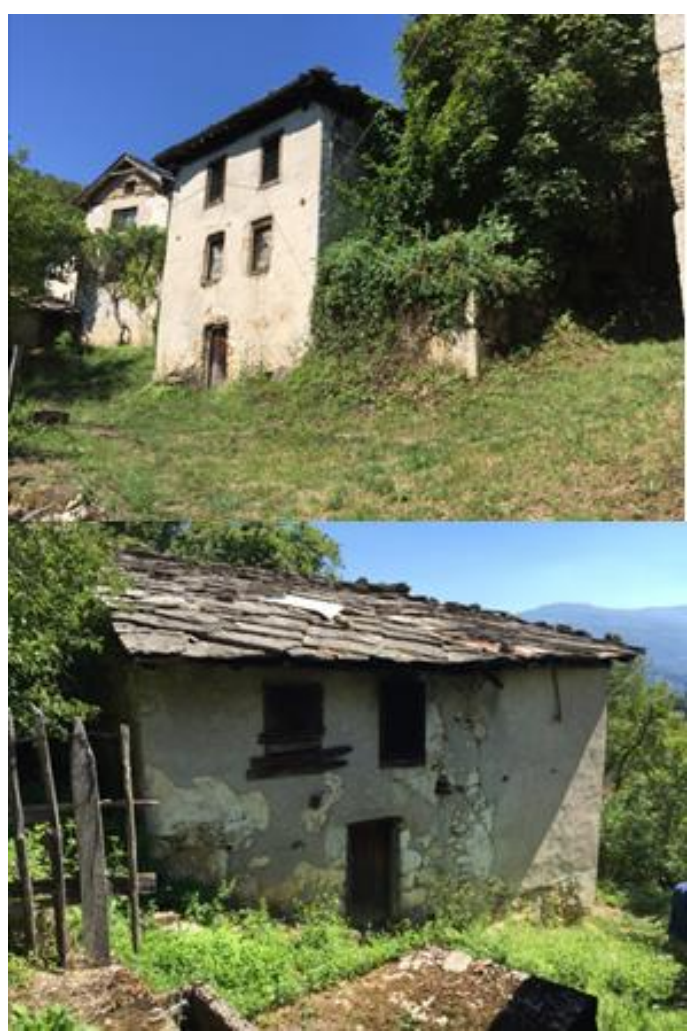

b)

Figure 3. Disposition (a) and appearance of the Smajić family house in Gorani near Konjic (b).

Source: drawing and photos: A. Hadrovic (2016) 

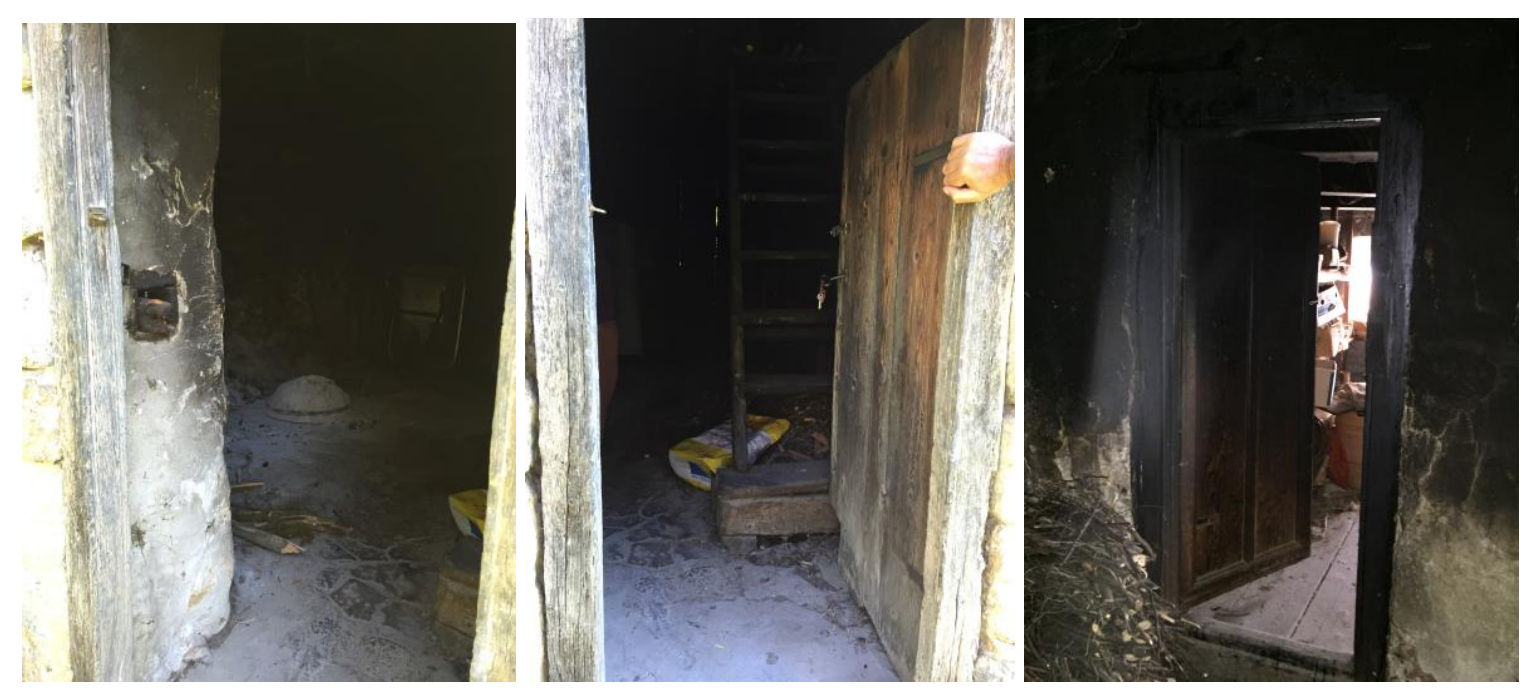

Figure 4. View from the front door to the fireplace in the "house" ("kuća"), a wooden staircase (basamake) that connects the space of the "house" and the first floor and a view from the space of the "house" ("kuća") to the space through the open room door.

Source: A. Hadrovic (2016)
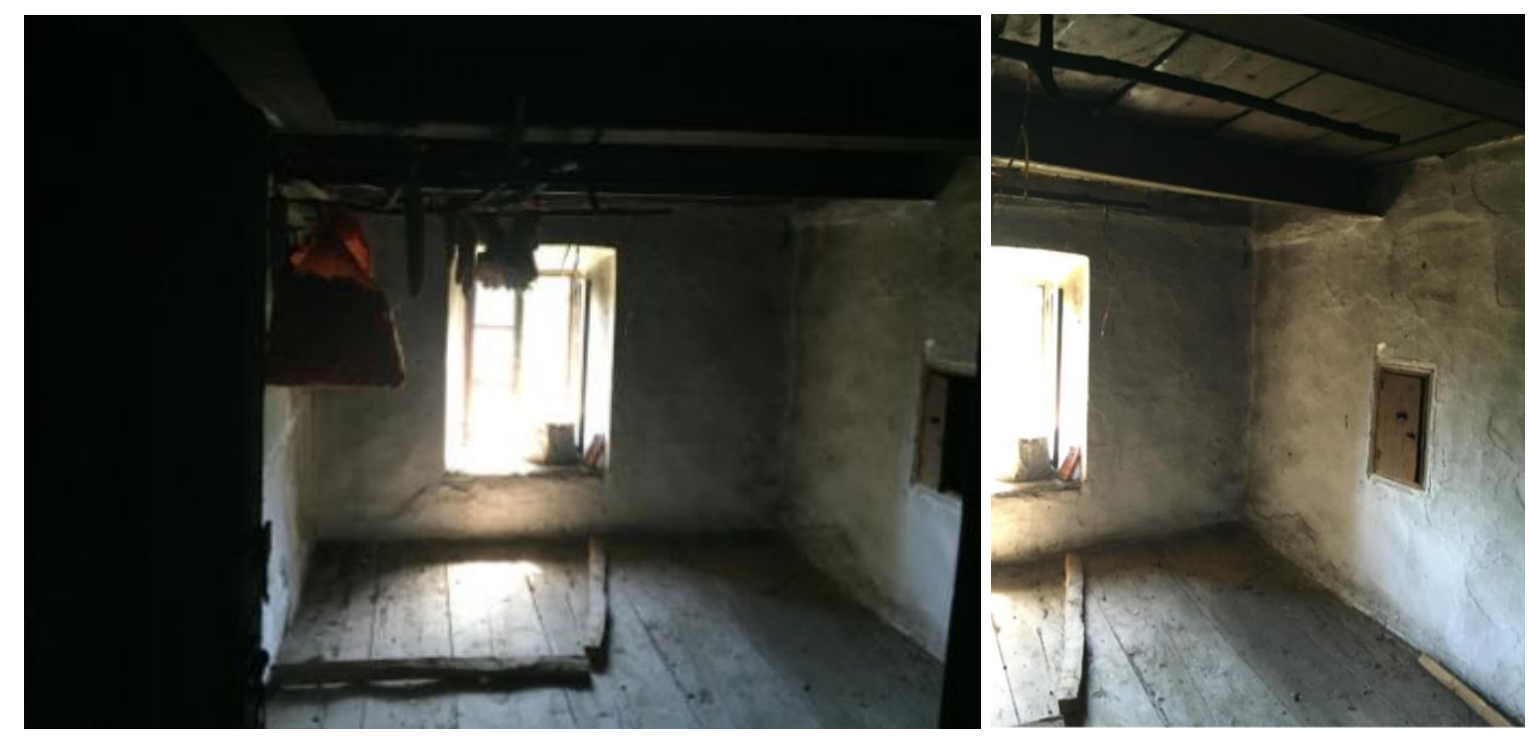

Figure 5. Chardak

Source: A. Hadrovic (2016)

\section{Construction and materialization}

The staircase ("basamaci") in the bosnian chardaklia house is, as a rule, made of wood. The height from the ground floor to the first floor (about 200-240 cm) is overcome by 8 to 11 heights of the staircase tread whose width is $28-32 \mathrm{~cm}$. The staircase is quite steep (Figure 6.), which is a consequence of the requirement that it take up as little space as possible. Almost as a rule, the space under the stairs is also used, as a special close. 
Wooden stairs ("basamaci") are, as a rule, made of two side girders made of wooden planks whose thickness is $5-10 \mathrm{~cm}$. these supports are cut into the treads and the front of the staircase from planks 3-5 cm thick. Stairs are made as "piece furniture" in a carpentry workshop, and are installed in a specific building as a "prefabricated" building element ${ }^{[15]}$. In case the space under the staircase is not used as a closet, the fronts on the steps are omitted, so that the staircase looks light and transparent.

The staircase is usually made of spruce wood, but also of beech, maple and elm. The treatment of the surfaces of the tread and the front of each step gives the staircase a special warmth that significantly contributes to the pleasant atmosphere of the residential building.

The significance of the staircase in the Bosnian chardaklia house is emphasized by the filigree wooden fence on their edge in the divanhana area, and sometimes by a special wooden "triumphal arch" or ceremonial gate at the beginning or end of the staircase. Such staircases are associated with the mimber, one of the important elements of furniture in mosques.
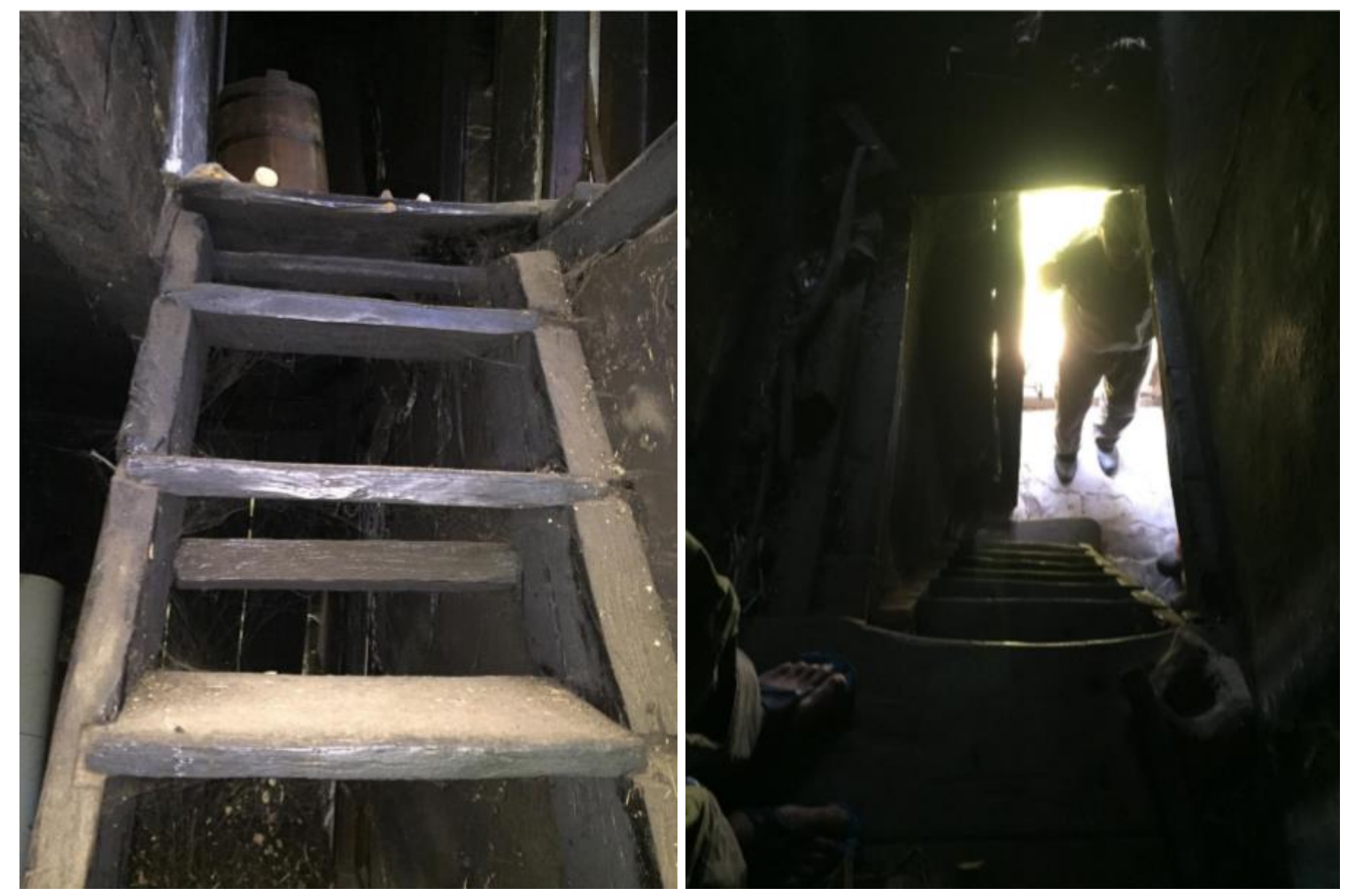

Figure 6. Staircase (basamaci) ground floor

Source: A. Hadrovic (2016) 

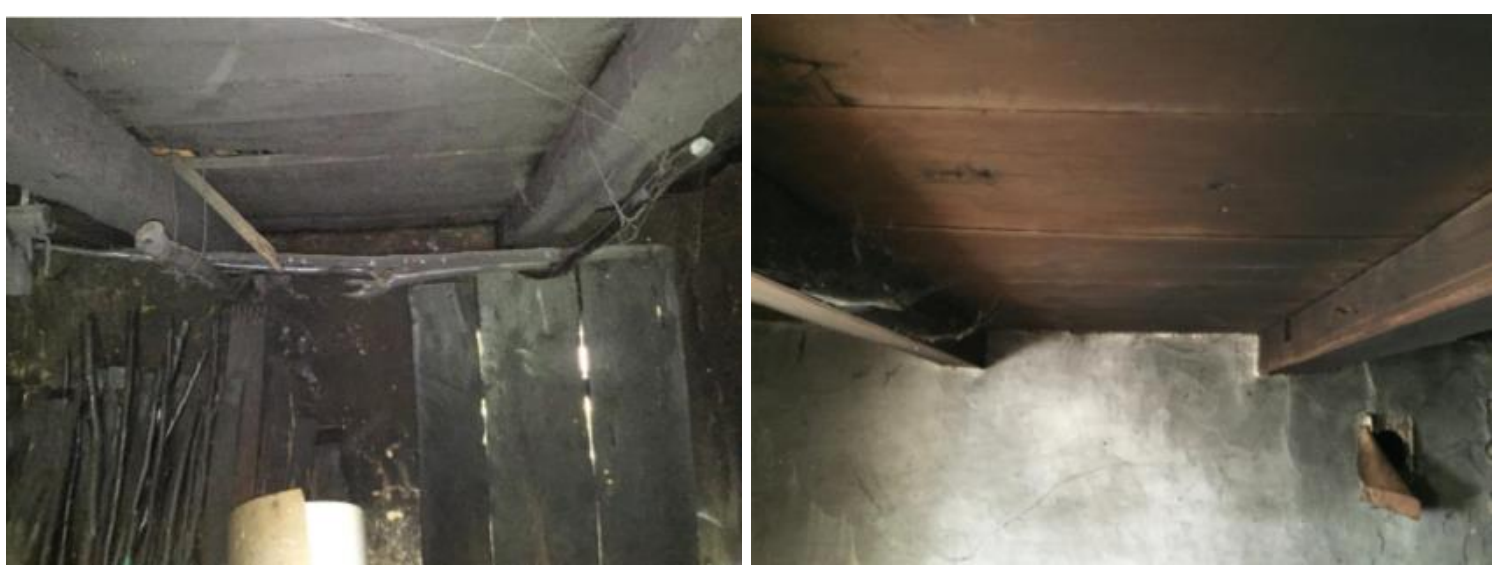

Figure 7. Ceiling construction (ground floor-first floor).

Source: A. Hadrovic (2016)

\section{Doors and windows}

The doors and windows of the Bosnian chardaklia house are most often made of spruce wood, but also of oak, maple, elm and beech wood. Although there is a wide range of different solutions for doors and windows, their standardization throughout Bosnia and Herzegovina is striking.

The door is an important element of the bosnian chardaklia house, as it represents the first physical contact of a man at his transition from the outer space to the house, ie from the space of the common inner space with the rooms of intimacy, rooms and chardaks.
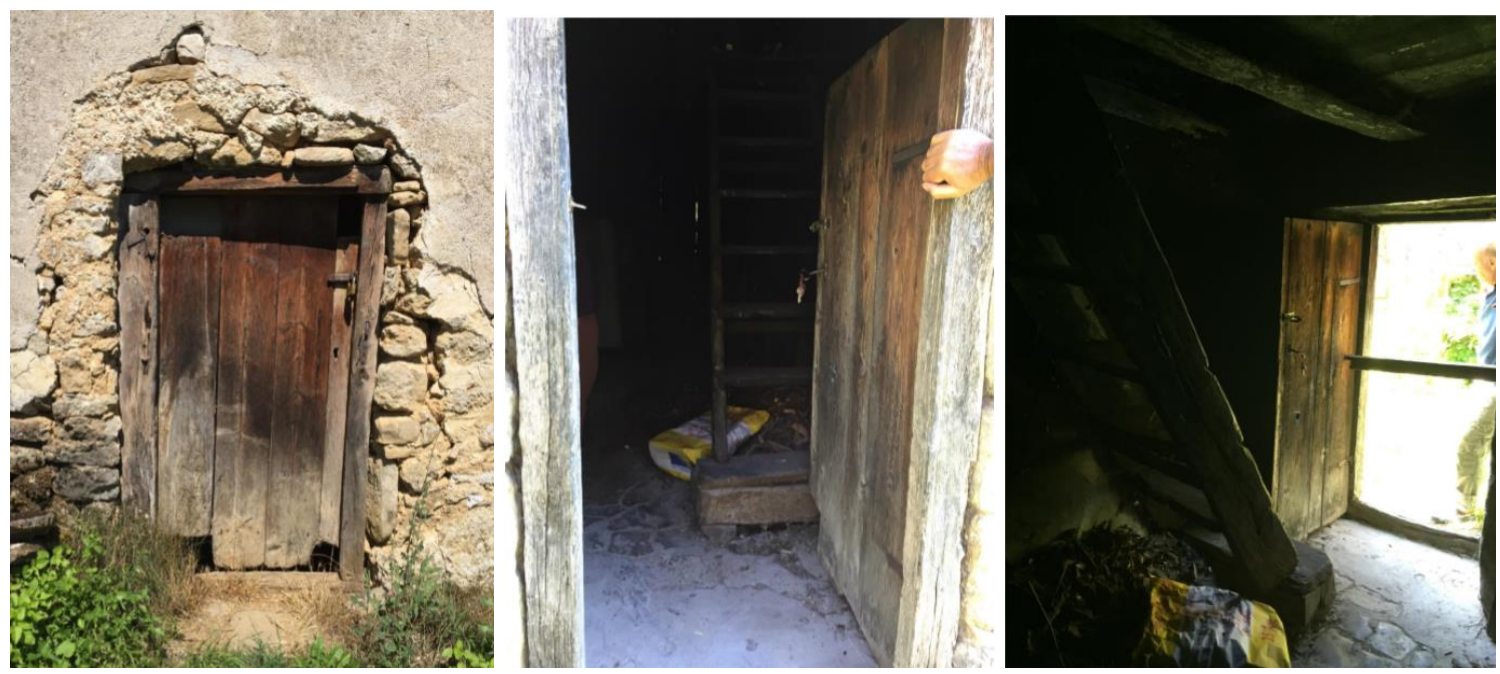

Figure 8. Basement door and front door (ground floor).

Source: A. Hadrovic (2016) 

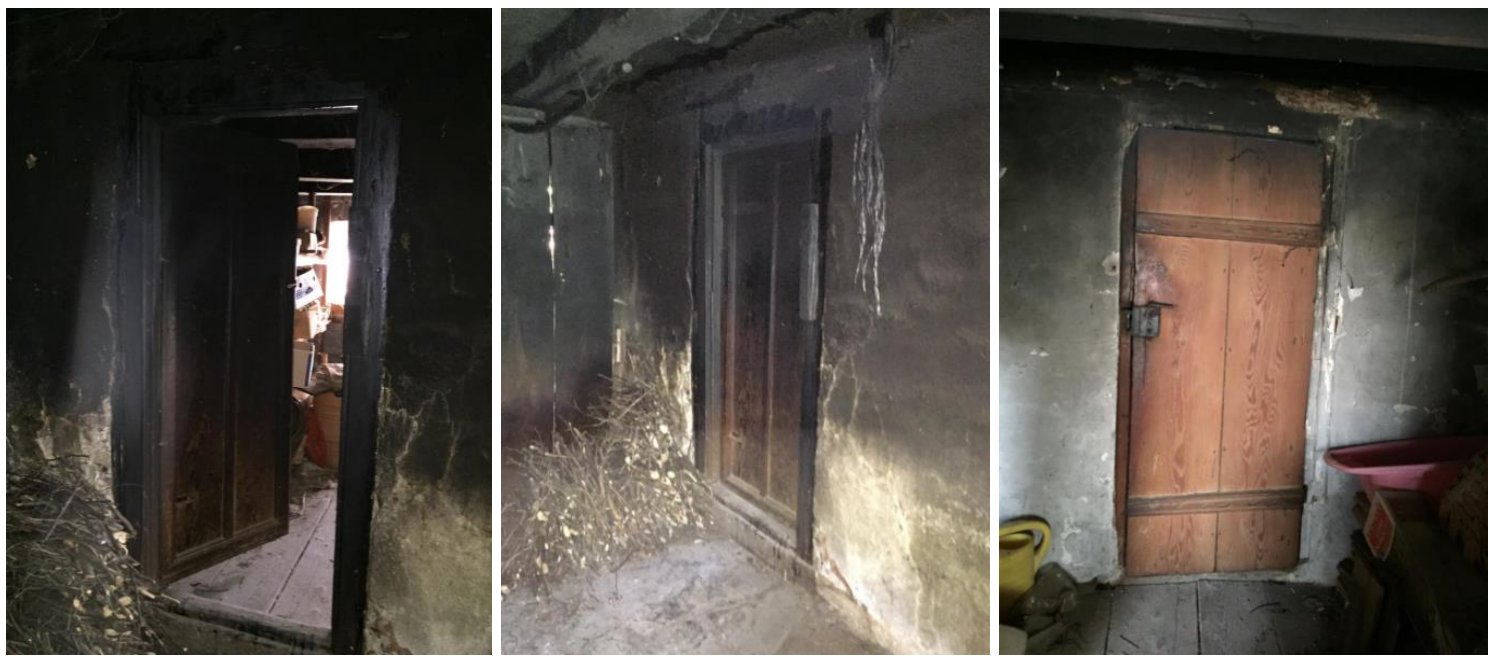

Figure 9. Doors on the rooms (on the ground floor).

Source: A. Hadrovic (2016)
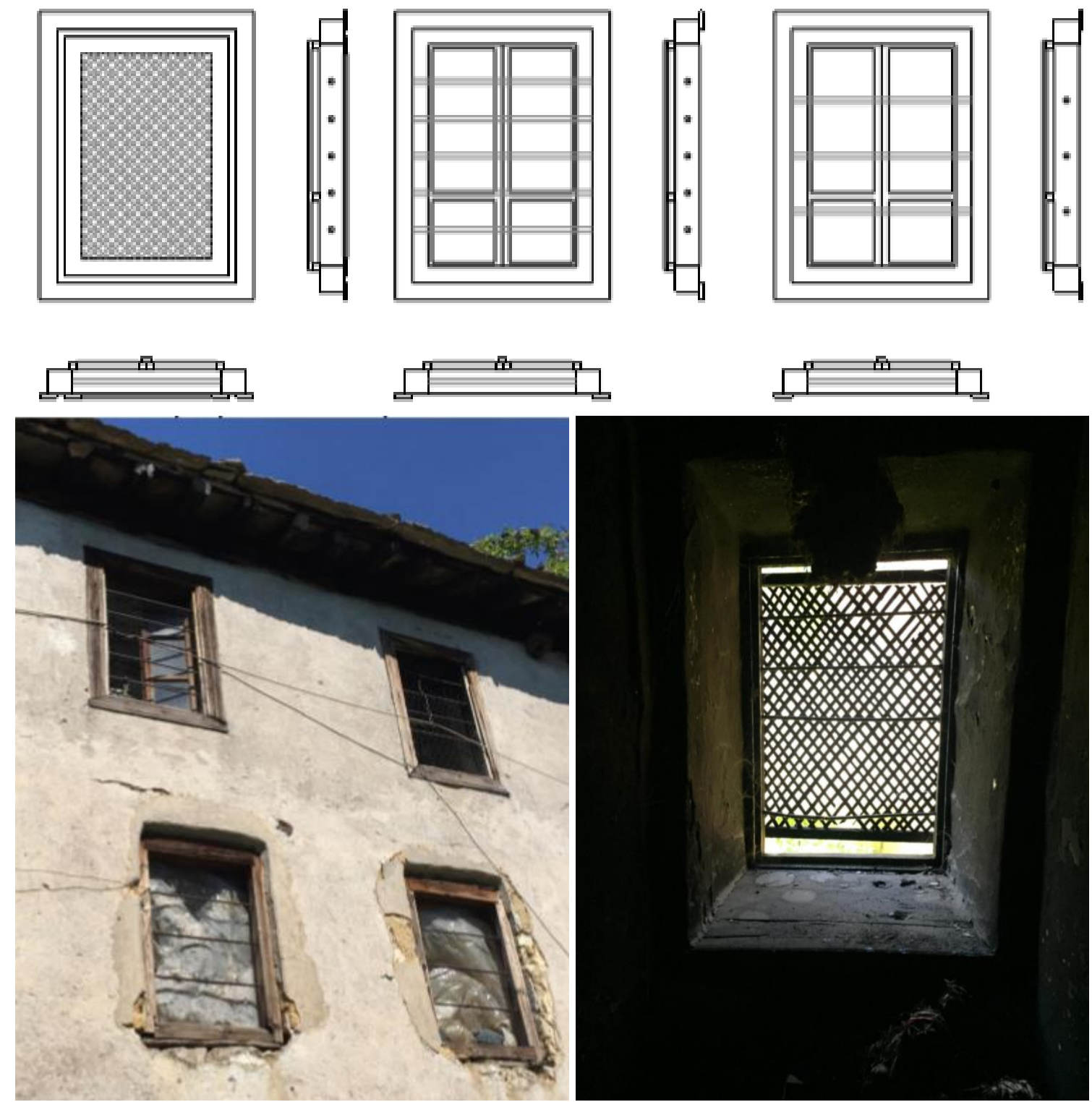

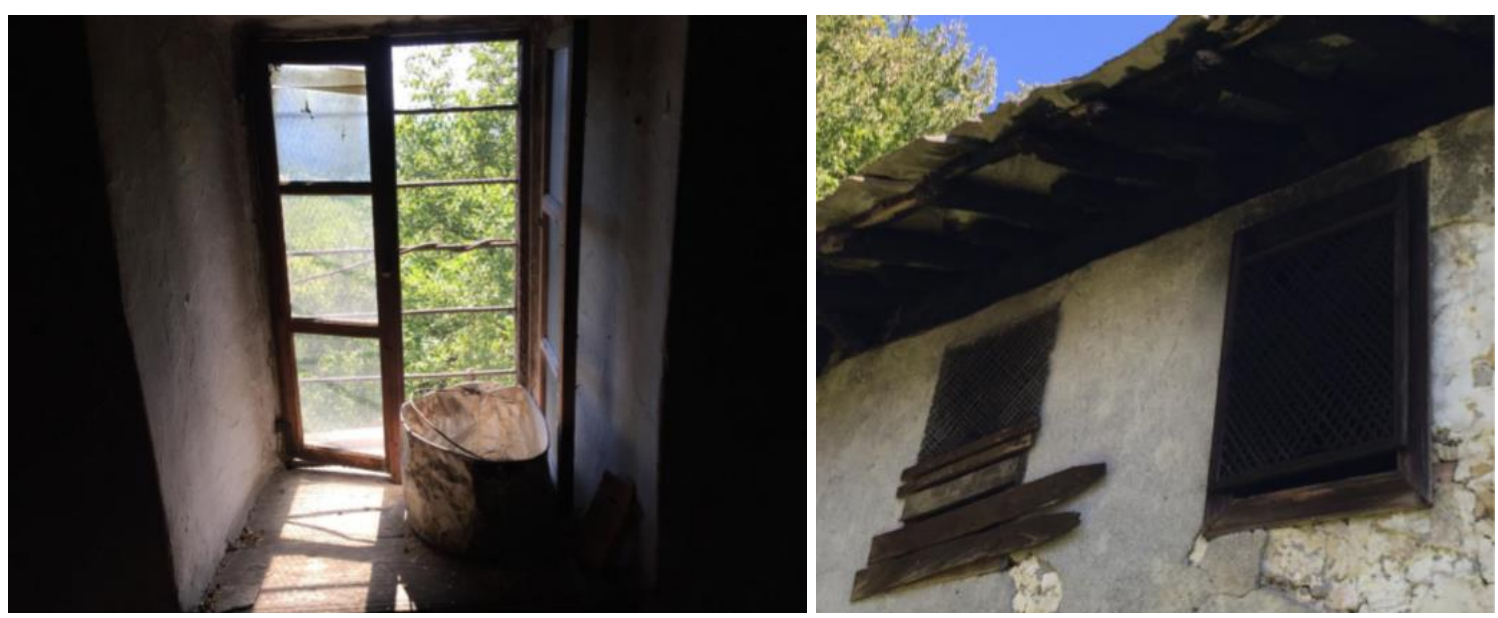

Figure 10. Window (on the main room on the ground floor).

Source: A. Hadrovic (2016)

\section{House equipment}

In the Smajic family house in Gorani near Konjic, the equipment of her premises has been reduced to a minimum. Premises are, conditionally speaking, „empty“, where their function is „activated“ by placing equipment that is located along the walls and ceilings. The central point of the living room (,house“ - „kuća“) is the fireplace, where the family gathers sitting on wooden chairs (,chemlia“ and „tripods“) which are usually made by the host of the house. The ,house“ also has the function of a kitchen where food is prepared and dishes are stored, in wall niches (,dulafs") and on shelves. The two rooms on the ground floor, which are accessed from the space of the „house“, are small in size. Sleeping beds (mattresses, quilts, pillows and sheets) are ,packed“ in the corner of the room, and ,activated as needed“. In the corner of each of these rooms is a small „bath“, a place for personal hygiene and ritual washing (,,abdest ${ }^{\text {“ }}{ }^{[14]}$. The wooden ceiling was also a „space“ for storing a number of useful household items (spinners for wool and hemp yarn, various knives, scissors, bookshelves...). Permanent food (,winter food") is kept in the basement room, and various household items are stored in the attic ${ }^{[16]}$.
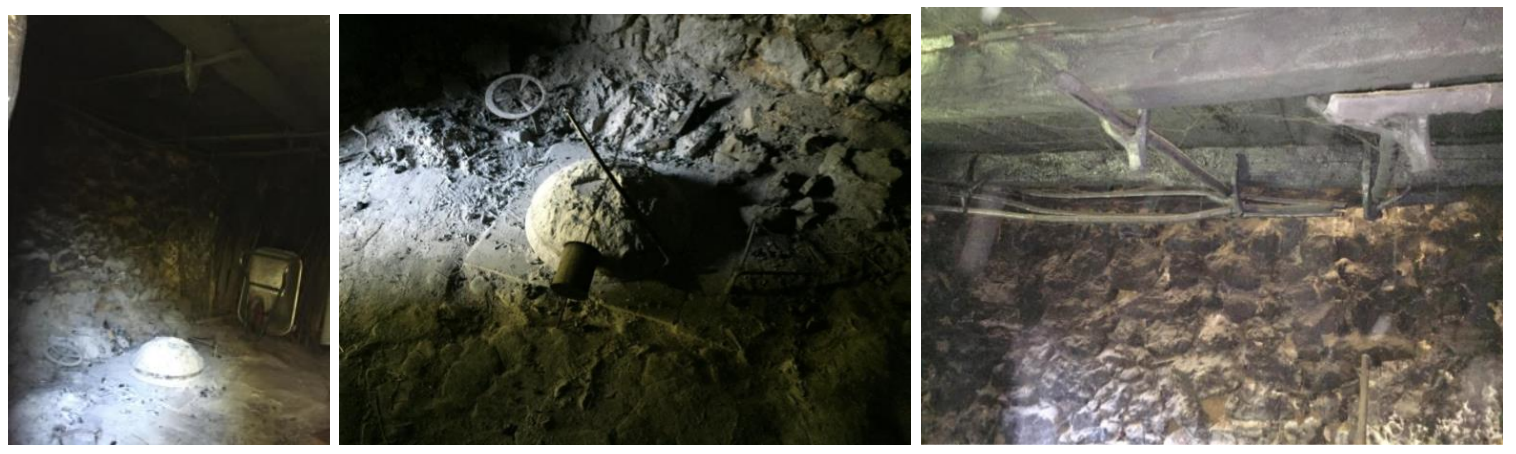

Figure 11. Fireplace in the "kuća" (Living room).

Source: A. Hadrovic (2016) 


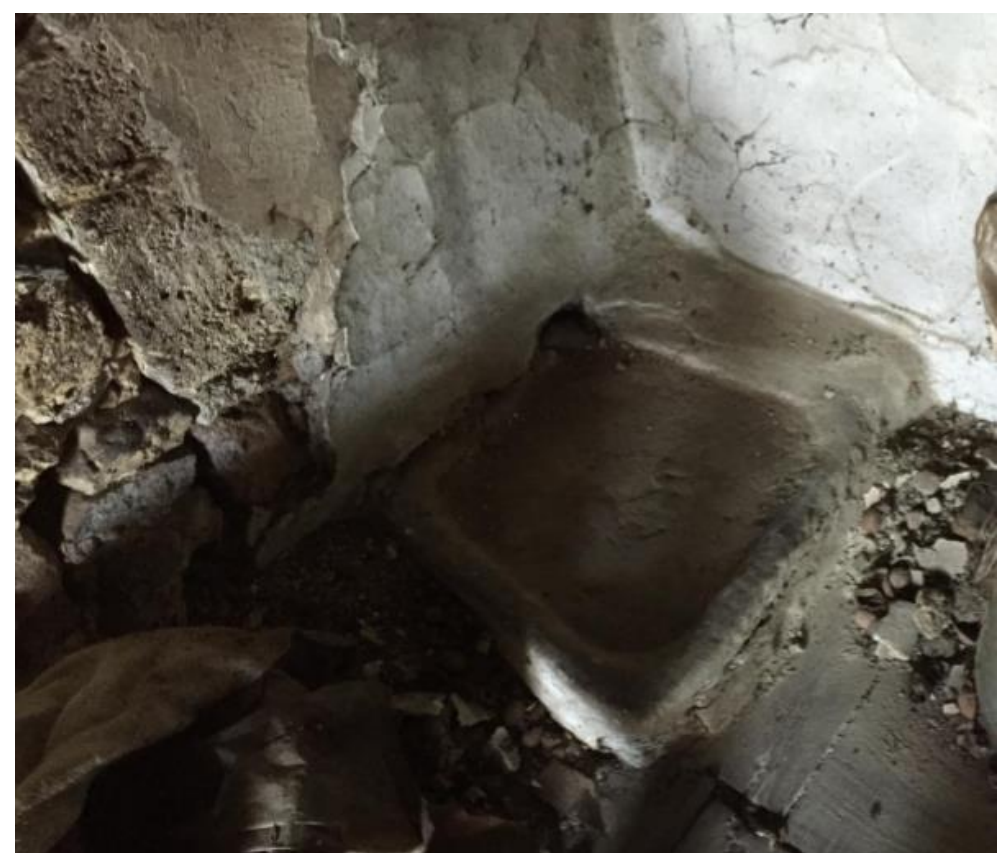

Figure 12. Bath tub (,banjica“) in one of the balconies

Source: A. Hadrovic (2016)

\section{Today's condition and purpose of the house}

All elements of the physical structure of the Smajic family house in Gorani near Konjic are still well preserved, bearing in mind that the house was built more than 150 years ago. All its current owners, as well as those who are not owners but were born or lived part of their lives in it, look at this house as their cradle, as the common denominator of the large Smajic family, as a symbol of the continuity of family existence. The house is not currently inhabited, but it is visited and its hearth is still used to prepare a particularly important meal, on the occasion of family or village (and even religious) celebrations. The house of the Smajic family in Gorani near Konjic is not the only house in the village of Gorani that has great architectural-historical and ambient values. There are several such houses, and they are of different ages and different levels of preservation.

\section{Conclusion}

The Smajic family house in Gorani near Konjic is an example of a traditional Bosnian chardaklia house and an example of bioclimatic architecture. In accordance with the natural and social environment, this house is an example of a more modest variant of the Bosnian chardaklia house which, compared to the more developed type of this house, is smaller and without semi-open spaces - divanhana (specific solutions of uncovered terraces on the first floor).

The features of the bioclimatic architecture of this house can be read in:

- Respect (selection) of slightly sloping terrain for its construction, as a rule with the southern exposure. The sloping terrain ideally generates the assumed scheme of its 
spatial development: basement (floor half-buried in the ground) intended for storing more durable food (winter), ground floor (floor where the living room is arranged „house“/"kuća"), as a multipurpose space where, in addition to the living room, kitchen with handy pantry (in wall niches and on shelves) and main room, also a multipurpose room and floor - floor where the chardak is arranged (usually a representative room and as a guest room) and attic, as a pantry for household tools ${ }^{[9}$, 16 ,

- Construction and materialization of the building, where traditional construction methods are used in many years of experience and the use of all materials from the immediate natural environment. In this way, this house appears to be a „man-made natural environment" ${ }^{[15]}$,

- Ensuring comfort in the house (in all seasons) is achieved by adequate shaping of the house, materialization of its envelope and the use of energy from the immediate environment (firewood, candles made of beeswax or sheep fat - before the introduction of electricity into the house) ${ }^{[16]}$,

- Recycling generated waste in the house. All human food scraps are given to domestic animals, while other types of waste are used as firewood (wood scraps in the making of household tools, for example) ${ }^{[9]}$,

- Use of rainwater to maintain the hygiene of people and rooms and laundry ${ }^{[9]}$,

- Thanks to the stability of the physical structure of the house, it is now used as a holiday home for people who live and work in the city. „The embodied spiritual energy of houses" (memories of childhood, parents and relatives, dear events) relaxes people and makes them especially confident in their attachment to ancestors ${ }^{[9]}$.

\section{References}

1) Cvijic, J. (1922), Balkansko poluostrvo i jugoslovenske zemlje, Beograd, p. 281- 282

2) Rodic, D. P. (1981), Geografija Jugoslavije I, Naucna knjiga, Beograd, p. 148

3) Hadrovic, A. (2007), Defining Architecrural Space on the Model of the Oriental Style City House in Bosnia and Herzegovina, Serbia, Montenegro, Kosovo and Macedonia, Booksurge, LLC, North Charleston, SC, USA, p. 2-3

4) Karanovic, M. (1927), O tipovima kuca u Bosni, Drzavna stamparija, Sarajevo, p. 4213

5) Soldo, S. (1932), Tipovi kuca i zgrada u predjasnjoj Bosni i Hercegovini, Drzavna stamparija Kraljevine Jugoslavije Beograd, p. 22

6) Deroko, A. (1964), Narodna arhitektura, knj. II, Naucna knjiga, Beograd, p. 28, 69

7) Kadic, Dr M. (1967), Starinska seoska kuca u BiH, Veselin Maslesa, Sarajevo, p. 57, 73,113

8) Hadrovic, A. (2017), Bosanska kuca cardaklija (Bosnian chardaklia house), Sarajevo, Arhitektonski fakultet u Sarajevu, Sarajevo, p. 937-966

9) Hadrovic, A. (2008), Bioclimatic Architecture, searching for a path to the Heaven, North Charlston, SC, USA, Booksurge, p. 136

10) Klaic, V. (1990), Povijest Bosne, fototip izdanja iz 1882. god., Svjetlost, Sarajevo, p. 345 
11) Imamovic, M. (1997), Historija Bosnjaka, Bosnjacka zajednica kulture Preporod, Sarajevo, p. 636

12) Malcolm, N. (2011), Bosna, kratka povijest, Buybook, Biblioteka Memorija, Sarajevo, p. 29

13) Kresevljakovic, H. (1991), Izabrana djela, knjiga II, Veselin Maslesa, Sarajevo, p. 491

14) Grozdanic, S. (1976), Uvod u arapsko-islamsku estetiku, Prilozi za orijentalnu filologiju, XXIV/1974. god., Orijentalni institut, Sarajevo, p. 56

15) Hadrovic, A. (2009), Structural Systems in Architecture, Booksurge, LLC, North Charleston, SC, USA, p. 138, 145

16) Hadrovic, A. (2010), Architectural Physics, Sarajevo, Faculty of Architecture University of Sarajevo, Sarajevo, p. 116-120 